\title{
SOIL LOSS ESTIMATION USING THE INTERO MODEL IN THE S1-2 WATERSHED OF THE SHIRINDAREH RIVER BASIN, IRAN
}

Jovana DRAGANIĆ ${ }^{1}$, Morteza BEHZADFAR ${ }^{2 *}$, Marx Leandro Naves SILVA ${ }^{3}$, Junior Cesar AVANZI ${ }^{4}$, Ivica KISIĆ ${ }^{5}$, Goran BAROVIĆ ${ }^{6}$,Velibor SPALEVIĆ ${ }^{6}$

\begin{abstract}
Soil erosion is one of the main problems of land degradation of agricultural land, especially in the mountainous areas. This negative process is one of the key problems to the environment and water resources in Iran. Using the computer-graphic modelling, we calculated sediment yield and peak discharge of the S1-2 catchment, of the Shirin-Dareh Basin of the Caspian Sea watershed. The area characterized cold winters (the minimum of $24.4^{\circ} \mathrm{C}$ ) and warm, dry summers (the absolute maximum air temperature of $34.6^{\circ} \mathrm{C}$; the average annual precipitation of $328 \mathrm{~mm}$ ). The coefficient of the region's permeability, S1, is calculated on 0.84 . The structure of the river basin, according to water permeability, is the following: f0, poor water permeability rocks, 53\%; fpp, medium permeable rocks, 41\%; fp, very permeable products from rocks: $6 \%$. The most common soil type in the studied area is Inceptisols with Calcic horizon. The river basin is under the mountain pastures $(51 \%)$ and the rest $(49 \%)$ is the ground without grass vegetation and plough-lands. The coefficient of the river basin planning is calculated on 0.75 . The coefficient of the vegetation cover is calculated on 0.9 . We calculated the soil losses from the S1-2 catchment on $20404 \mathrm{~m}^{3} \mathrm{yr}^{-1}$ and the peak discharge on $209 \mathrm{~m}^{3} \mathrm{~s}^{-1}$ (for the incidence of 100 years). The value of the $\mathrm{Z}$ coefficient of 0.917 indicates that the river basin belongs to the second destruction category, where the strength of the erosion process is high. With this study we provided new information about the recent state of the sediment yield of the S1-2 catchment, of the ShirinDareh Basin in the North Khorasan province of Iran in formats that can simplify the management in the watersheds, demonstrating the possibility of Soil Loss Estimation using the IntErO Model.
\end{abstract}

Keywords: soil erosion, IntErO Model, sediment yield, ShirinDareh watershed

\footnotetext{
${ }^{1}$ University of Montenegro, Biotechnical Faculty, Mihaila Lalića 1, 81000 Podgorica, Montenegro

${ }^{2}$ North Khorasan Provincial FRWO, Iran

${ }^{3}$ Federal University of Lavras, Department of Soil Science, Lavras, Brazil

${ }^{4}$ University of São Paulo, College of Animal Science and Food Engineering, Pirassununga, Brazil

${ }^{5}$ Faculty of Agriculture, University of Zagreb, Croatia

${ }^{6}$ Department of Geography, Faculty of Philosophy Niksic, University of Montenegro

*Corresponding author: mbehzadfar@gmail.com
} 


\section{INTRODUCTION}

Various environmental problems are involving the destruction of the natural balance as a result of the misuse or abuse of nature. Soil is one of the basic elements of nature and its problems are essential environmental problems (Dengiz and Akgül, 2005).

Soil degradation caused by erosion, together with rapid population increase, are ranked as the most important environmental problems in the world (Pimentel, 2006; Nikkami, 2012, Stoffel and Huggel, 2012, Ristic et al., 2001) where the erosion is a key driver of land degradation heavily affecting sustainable land management in various environments worldwide (Stoffel et al., 2013; Verheijen et al., 2009); the biggest threat to the conservation of soil and water resources (Bayramin et al., 2003).

Soil erosion is a growing problem globally and is serious problem in Iran. The off-site impact of loss of reservoir capacity is increasing in this Region. Quantitative information on soil loss is needed for erosion risk assessment. The modelling of the erosion process has progressed rapidly, and a variety of models have been developed to predict both runoff and soil loss. The authors of this study used the computer - graphic models (Spalevic, 2011; Spalevic, 1999a) for prediction of soil erosion intensity from the catchment area - IntErO model (Spalevic, 2011).

The objective of this research was characterization of the erosion processes in relation to the recent state of the sediment yield in the S1-2 Watershed of the Shirindareh River Basin. The results, consistent with previous researches on the neighbouring river basins, presented in formats that may be further used for the efficient management and protection, illustrating the possibility of modelling sediment yield by the IntErO model.

\section{MATERIAL AND METHODS}

The study was conducted in the area of the S1-2 watershed of the Shirindareh River Basin of the Caspian Sea Watershed (Figure 1).

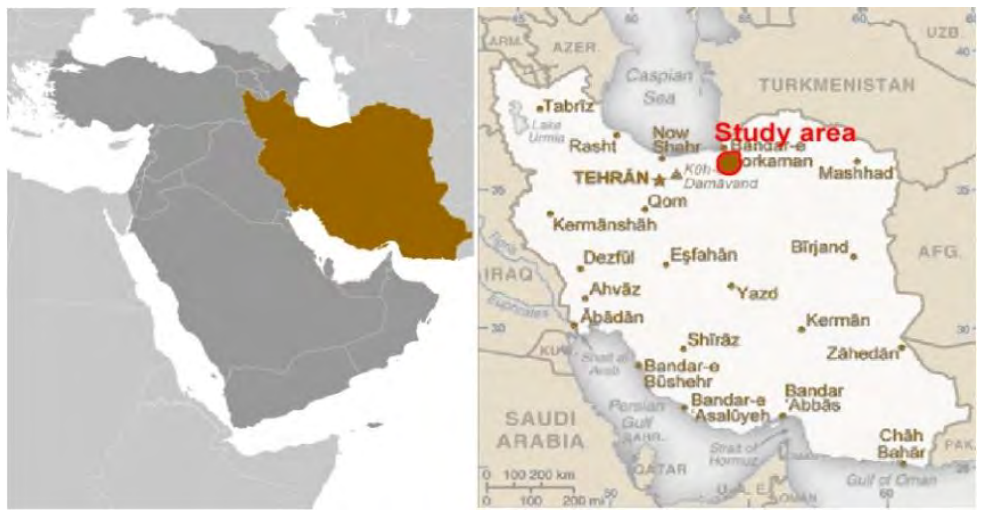

Figure 1. Study area of the S1-2 watershed, the Shirindareh River Basin, Iran 
The studied river basin is placed in the mountainous area of the north-eastern part of Iran. The river dam has been constructed on the main river of the basin; surface runoff is used for supply of water for drinking and agriculture and it is important to keep the reservoir in good condition, decreasing sedimentation and controlling the runoff at the upstream watersheds (Behzadfar et al., 2015).

The S1-2 watershed is covering an area of $56 \mathrm{~km}^{2}$. It is one of the medium to big sized watersheds of the natural entity of the Shirindareh region. During the field work, using a morphometric methods, various data on intensity and forms of soil erosion, land use, and the measures taken to reduce or mitigate erosion were recorded.

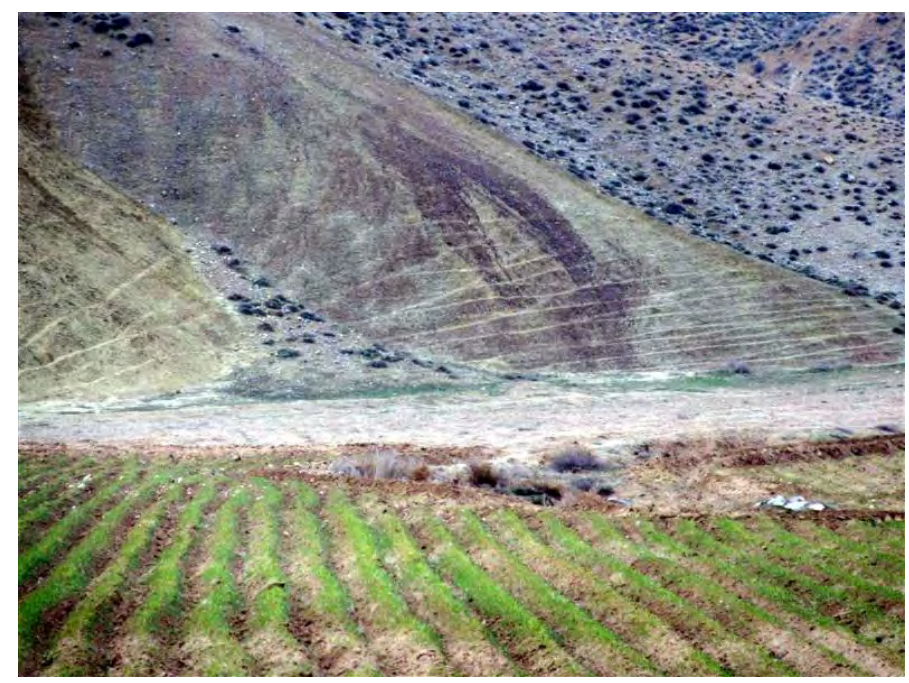

Figure 2. Details from the filed visit on the Shirindareh River Basin, Iran V. Spalevic \& M. Behzadfar (Feb. 2015): Problems with overgrazing and livestock traces

According to our calculations, the shortest distance between the fountainhead and the mouth, $1 \mathrm{v}$, is $7.5 \mathrm{~km}$; and the total length of the main watercourse with tributaries is 129 $\mathrm{km}$. The relief has very pronounced dynamics; the average slope gradient in the river basin, Isr, is calculated on $26 \%$ what indicates that in the river basin prevailing steep slopes. The average river basin altitude Hsr, is calculated on $1700 \mathrm{~m}$; the average elevation difference of the river basin, $\mathrm{D}$, on $274 \mathrm{~m}$.

The analysis of the geological structure and soil characteristics of the area was based on the research of the National Geological Survey Organization (NGS) led by Bolourchi (1987), who analysed the physical and chemical properties of all geological formations of North Khorasan province, including those in the study area of the S1-2 
Basin. Climatological data were received from the North Khorasan Meteorological stations of Iran.

For obtaining data on forecasts of sediment yield and peak discharge from the basin we used the IntErO model (Intensity of Erosion and Outflow - program package; Spalevic, 2011), with the Erosion Potential Method - EPM (Gavrilovic, 1972) embedded in the algorithm of this computer-graphic method.

The basic analytical equation for the calculation of erosion-induced soil losses, as developed by Gavrilovic (1972), is as follows:

$$
G_{y r \times s p^{11}}=T \times H_{y r} \times \pi \sqrt{Z^{3}} \times R_{u}
$$

where: $\mathrm{G}_{\mathrm{yr} \mathrm{sp}}{ }^{-1}$ - specific annual total erosion-induced sediment yield reaching the confluence, $\mathrm{m}^{3}$ $\mathrm{yr}^{-1} \mathrm{~km}^{-2} ; \mathrm{T}-$ temperature coefficient of the catchment; $\mathrm{H}_{\mathrm{yr}}-$ amount of rainfall, $\mathrm{mm} ; \pi$ - 3.14; $\mathrm{Z}$ - coefficient of erosion; $\mathrm{R}_{\mathrm{u}}-$ coefficient of retention of soil in the catchment.

This methodology is currently in use in: Bosnia \& Herzegovina, Brazil, Bulgaria, Croatia, Czech Republic, Italy, Macedonia, Montenegro, Morocco, Serbia, South Africa and Slovenia (Gazdic et al., 2015; Spalevic et al., 2015a, 2015b, 2015c, 2015d, 2015e, 2015f, 2015g, 2015h, 2015i, 2015k; Kostadinov et al., 2014, Curovic et al., 1999). In Iran have been successfully used in the regions of Chamgardalan, Kasilian, Kermanshah, Razavi Khorasan (Barovic et al., 2015; Behzadfar et al., 2015; Behzadfar et al., 2014a; Behzadfar et al., 2014b; Sadeghi, 2005, Sadeghi, 1993; Yousefi et al.; 2014; Zia Abadi \& Ahmadi, 2011; Amiri, 2010) and other regions.

\section{RESULTS AND DISCUSSION}

The climate in the studied area is continental, with the absolute maximum air temperature of $34.6^{\circ} \mathrm{C}$ and the negative $-24.4^{\circ} \mathrm{C}$. The average annual air temperature, $\mathrm{t} 0$, is $10.2^{\circ} \mathrm{C}$. The average annual precipitation, $\mathrm{H}_{\mathrm{yr}}$, is $328.4 \mathrm{~mm}$ (Source: Data from the North Khorasan Meteorological stations of Iran).

The temperature coefficient of the region, $\mathrm{T}$, is calculated on 1.06; the amount of torrential rain, hb, on $35.61 \mathrm{~mm}$.

Vegetation and land use. The studied area is located in Middle- East of the Kope-Dagh geographical region. According to the available literature and the analysis using the Google maps and Google Earth, including the records from the field visits, the pastures and meadows are covering the area of $51 \%$ and non-arable land of $49 \%$. The coefficient of the river basin planning, $\mathrm{Xa}$, is calculated on 0.75 . The coefficient of the vegetation cover, $\mathrm{S} 2$, is calculated on 0.9 . 
Soil erosion and runoff characteristics. The dominant erosion form in this area is surface erosion and is the most pronounced on the steep slopes without vegetation cover. Problems with overgrazing and livestock traces are recorded also all over the studied area.

Processing the input data by the IntErO model we received the results in relation to the sediment yield of the S1-2 Watershed of the Shirindareh River Basin of Iran. The results are presented at the Table 1 .

Table 1. The IntErO report for the S1-2 watershed river basin

\begin{tabular}{|c|c|c|c|}
\hline River basin area & $\mathrm{F}$ & 56.06 & $\mathrm{~km}^{2}$ \\
\hline The length of the watershed & $\mathrm{O}$ & 40.28 & $\mathrm{~km}$ \\
\hline Natural length of the main watercourse & $\mathrm{Lv}$ & 7.54 & $\mathrm{~km}$ \\
\hline The shortest distance between the fountainhead and mouth & $\mathrm{Lm}$ & 6.59 & $\mathrm{~km}$ \\
\hline The total length of the main watercourse with tributaries of I and II class & $\Sigma \mathrm{L}$ & 128.97 & $\mathrm{~km}$ \\
\hline River basin length measured by a series of parallel lines & $\mathrm{Lb}$ & 11.81 & $\mathrm{~km}$ \\
\hline The area of the bigger river basin part & $\mathrm{Fv}$ & 31.64 & $\mathrm{~km}^{2}$ \\
\hline The area of the smaller river basin part & $\mathrm{Fm}$ & 24.42 & $\mathrm{~km}^{2}$ \\
\hline Altitude of the first contour line & h0 & 1500 & $\mathrm{~m}$ \\
\hline The lowest river basin elevation & Hmin & 1426 & $\mathrm{~m}$ \\
\hline The highest river basin elevation & Hmax & 2189 & $\mathrm{~m}$ \\
\hline A part of the river basin consisted of a very permeable products from rocks & $\mathrm{fp}$ & 0.06 & \\
\hline A part of the river basin area consisted of medium permeable rocks & fpp & 0.41 & \\
\hline A part of the river basin consisted of poor water permeability rocks & fo & 0.53 & \\
\hline A part of the river basin under grass, meadows, pastures and orchards & $\mathrm{ft}$ & 0.51 & \\
\hline A part of the river basin under plough-land and without vegetation & fg & 0.49 & \\
\hline The volume of the torrent rain & $\mathrm{hb}$ & 36.16 & $\mathrm{~mm}$ \\
\hline Average annual air temperature & to & 9.8 & ${ }^{\circ} \mathrm{C}$ \\
\hline Average annual precipitation & Hyr & 335 & $\mathrm{~mm}$ \\
\hline Types of soil products and related types & $\mathrm{Y}$ & 1.1 & \\
\hline River basin planning, coefficient of the river basin planning & $\mathrm{Xa}$ & 0.75 & \\
\hline Numeral equivalents of visible and clearly exposed erosion process & $\varphi$ & 0.59 & \\
\hline Coefficient of the river basin form & A & 1.04 & \\
\hline Coefficient of the watershed development & $\mathrm{m}$ & 0.28 & \\
\hline Average river basin width & B & 4.75 & $\mathrm{~km}$ \\
\hline (A)symmetry of the river basin & $\mathrm{a}$ & 0.26 & \\
\hline Density of the river network of the basin & $\mathrm{G}$ & 2.3 & \\
\hline Coefficient of the river basin tortuousness & $\mathrm{K}$ & 1.14 & \\
\hline
\end{tabular}




\begin{tabular}{|c|c|c|c|}
\hline Average river basin altitude & Hsr & 1700.45 & $\mathrm{~m}$ \\
\hline Average elevation difference of the river basin & $\mathrm{D}$ & 274.45 & $\mathrm{~m}$ \\
\hline Average river basin decline & Isr & 26.01 & $\%$ \\
\hline The height of the local erosion base of the river basin & Hleb & 763 & $\mathrm{~m}$ \\
\hline Coefficient of the erosion energy of the river basin's relief & $\mathrm{Er}$ & 88.76 & \\
\hline Coefficient of the region's permeability & S1 & 0.84 & \\
\hline Coefficient of the vegetation cover & S2 & 0.9 & \\
\hline Analytical presentation of the water retention in inflow & $\mathrm{W}$ & 0.4838 & $\mathrm{~m}$ \\
\hline Energetic potential of water flow during torrent rains & $2 \mathrm{gDF}^{\wedge 1 / 2}$ & 549.42 & $\mathrm{~m} \mathrm{~km} \mathrm{~s}$ \\
\hline Maximal outflow from the river basin & Qmax & 209.29 & $\mathrm{~m}^{3} / \mathrm{s}$ \\
\hline Temperature coefficient of the region & $\mathrm{T}$ & 1.04 & \\
\hline Coefficient of the river basin erosion & $\mathrm{Z}$ & 0.917 & \\
\hline Production of erosion material in the river basin & Wyr & 53820.52 & $\mathrm{~m}^{3 / \mathrm{yr}}$ \\
\hline Coefficient of the deposit retention & $\mathrm{Ru}$ & 0.379 & \\
\hline Real soil losses & Gyr & 20404.44 & $\mathrm{~m}^{3} / \mathrm{yr}$ \\
\hline Real soil losses per $\mathrm{km}^{2}$ & $\mathrm{Gyr} / \mathrm{km}^{2}$ & 363.98 & $\mathrm{~m}^{3} / \mathrm{km}^{2} \mathrm{yr}$ \\
\hline
\end{tabular}

The coefficient of the river basin form, A, is calculated on 1.04. Coefficient of the watershed development, $\mathrm{m}$, is 0.28 and average river basin width, $\mathrm{B}$, is $4.75 \mathrm{~km}$. (A)symmetry of the river basin, a, is calculated on 0.26 and that indicates that there is a possibility for large flood waves to appear in the studied river basin. The value of $G$ coefficient of 2.3 indicates there is very high density of the hydrographic network.

The height of the local erosion base of the river basin, Hleb, is $763 \mathrm{~m}$. Coefficient of the erosion energy of the river basin's relief, Er, is calculated on 88.76. According to the erosion type, the dominant process is surface erosion.

The value of $Z$ coefficient of 0.917 indicates that the river basin belongs to II destruction category. The strength of the erosion process is high, and according to the erosion type, it is intrusive erosion. We calculated the soil losses from the S1-2 catchment on 20404 $\mathrm{m}^{3} \mathrm{yr}^{-1}$ and the peak discharge on $209 \mathrm{~m}^{3} \mathrm{~s}^{-1}$ (for the incidence of 100 years).

\section{CONCLUSIONS}

Sediment yield and peak discharge of the S1-2 catchment of the Shirin-Dareh Basin of the Caspian Sea watershed were calculated using the computer-graphic modelling. The results of the processing of the inputs, using the IntErO model, are the following:

- The structure of the river basin, according to water permeability, is the following: f0, poor water permeability rocks, $53 \%$; fpp, medium permeable 
rocks, $41 \%$; fp, very permeable products from rocks: $6 \%$. The coefficient of the region's permeability, $\mathrm{S} 1$, is calculated on 0.84 .

- The most common soil type in the studied area is Inceptisols with Calcic horizon.

- The river basin is under the mountain pastures (51\%) and the rest (49\%) is the ground without grass vegetation and plough-lands.

- The coefficient of the river basin planning is calculated on 0.75 .

- The coefficient of the vegetation cover is calculated on 0.9 .

- Calculated soil losses from the S1-2 catchment are $20404 \mathrm{~m}^{3} \mathrm{yr}^{-1}$ and the peak discharge is $209 \mathrm{~m}^{3} \mathrm{~s}^{-1}$ (for the incidence of 100 years).

- The value of the $\mathrm{Z}$ coefficient of 0.917 indicates that the river basin belongs to the second destruction category, where the strength of the erosion process is high.

With this study we provided new information about the recent state of the sediment yield of the S1-2 catchment, of the Shirin-Dareh Basin in the North Khorasan province of Iran in formats that can simplify the management in the watersheds, demonstrating the possibility of Soil Loss Estimation using the IntErO Model. For more reliable conclusions measurements are needed for the model verification, including additional analysis in relation to the land use changes.

This study further confirmed the findings of Barovic et al., 2015; Behzadfar et al., 2015, 2014a, 2014b; Amini et al., 2014; Yousefi et al., 2014; Moradi et al., 2015; Zia Abadi \& Ahmadi, 2011; as well as Amiri, 2010; Khaleghi, 2005; Maleki, 2003; Nadjafi, 2003; Sadeghi 1993 in possibility of implementing the Erosion Potential Method in Iran, what leads to the conclusion that the IntErO model may be a useful tool for researchers in calculation of runoff and sediment yield for the river basins of the Caspian Sea Watershed with the similar physical-geographical characteristics like the Shirindareh river basins. We would like to highlight that the team of authors have the same good experience about the simplicity in operation and practicality in use of the IntErO also in the Saudi Arabia (Al-Turki et al., 2015) and in the Western Balkans (Barovic \& Spalevic, 2015; Vujacic \& Spalevic, 2015; Spalevic et al., 2014a, 2014b, 2014c, 2014d, 2013a, 2013b, 2013c, 2013d, 2013e, 2003a, 2003b, 1999b, 1999c).

\section{ACKNOWLEDGEMENTS}

This research was concluded by the two teams of the scholars from Brazil and Montenegro, (cooperation between the researchers of the two countries in the area of soil conservation and watershed management). Field work was carried out in 2014 and 2015, funded by the Natural Resources and Watershed Management Office, North Khorasan of Iran. 


\section{REFERENCES}

Ali M. Al-Turki, A.M., Ibrahim, H.M., Spalevic, V., 2015. Impact of land use changes on soil erosion intensity in Wadi Jazan watershed in southwestern Saudi Arabia. Agrosym 2015, Jahorina, Bosnia and Herzegovina; 10/2015

Amiri, F., 2010. Estimate of Erosion and Sedimentation in Semi-arid Basin using Empirical Models of Erosion Potential within a Geographic Information System. Air, Soil and Water Research, 3: 37-44.

Ballesteros-Cánovas, J.A., Czajka, B., Janecka, K., Lempa, M., Kaczka, R.J., Stoffel, M. 2015. Flash floods in the Tatra Mountain streams: Frequency and triggers. Science of the Total Environment 511: 639-648.

Barovic, G. and Spalevic, V. 2015. Calculation of runoff and soil erosion intensity in the Rakljanska Rijeka Watershed, Polimlje, Montenegro. The 6th International Symposium Agrosym 2015, Jahorina, 15-18 October 2015, Bosnia and Herzegovina.

Barovic, G., Leandro Naves Silva, M., Veloso Gomes Batista, P., Vujacic, D., Soares Souza, W., Cesar Avanzi, J., Behzadfar M., Spalevic, V. 2015. Estimation of sediment yield using the IntErO model in the S1-5 Watershed of the Shirindareh River Basin, Iran. Agriculture and Forestry 61(3): 233-243

Bayramin, İ., Dengiz, O., Başkan, O., Parlak, M. 2003, Soil Erosion Risk Assessment with ICONA Model; Case Study: Beypazarı Area. Turk J Agric For. 27, p 105-116.

Behzadfar, M. Tazioli, A., Vukelic-Shutoska, M., Simunic, I., and Spalevic, V. (2014b). Calculation of sediment yield in the S1-1 Watershed, Shirindareh Watershed, Iran. Agriculture and Forestry, 60 (4): 207-216.

Behzadfar, M., Curovic, M., Simunic, I., Tanaskovik, V., Spalevic, V. 2015. Calculation of soil erosion intensity in the S5-2 Watershed of the Shirindareh River Basin, Iran. International Conference on Soil, Tirana, Albania; 4-7 May, 2015.

Behzadfar, M., Djurovic, N., Simunic, I., Filipovic, M. and Spalevic, V. (2014a): Calculation of soil erosion intensity in the S1-6 Watershed of the Shirindareh River Basin, Iran. International Scientific conference: Challenges in modern agricultural production, December 11, 2014, Skopje, Macedonia.

Curovic, M., Spalevic, V., Dozic, S., Dubak, D. (1999): Proposal of Anti Erosion Regulation of Department 17 of Husbandry Unit Rudo Polje-Kovren. Agriculture and Forestry, 45 (3-4): 5-23.

Dengiz, O., Akgül, S., 2005. Soil Erosion Risk Assessment of the Gölbaşı Environmental Protection Area and Its Vicinity Using the CORINE Model. Turk J Agric For. 29, p 439-448.

Gazdic, M., Pejovic, S., Vila, D., Vujacic, D., Barovic, G., Djurovic, N., Tanaskovikj, V., and Spalevic, V. 2015. Soil erosion in the Orahovacka Rijeka Watershed, 
Montenegro. The 6th International Symposium Agrosym 2015, Jahorina, 15-18 October 2015, Bosnia and Herzegovina.

Kostadinov, S., Zlatic, M., Dragicevic, S., Novkovic, I., Kosanin, O., Borisavljevic, A., Lakicevic, M., Mladjan, D., 2014. Anthropogenic influence on erosion intensity changes in the Rasina river watershed - Central Serbia.

Nikkami, D., 2012. Investigating sampling accuracy to estimate sediment concentrations in erosion plot tanks. Turk J Agric For 36: 583-590.

Pimentel, D., 2006. Food and environmental threat of soil erosion. J Env Dev and Sustain 8: 119-137.

Ristic, R., Kostadinov, S., Malosevic, D., Spalevic, V. 2001. Erosion aspect in the assessment of soils of hydrologic classes and determination of $\mathrm{CN}$ number of runoff curve. Acta biologica Iugoslavica - serija A: Zemljište i biljka. 2001, vol. 50, No 3, p.165-174.

Sadeghi, H. 1993. Comparison of some erosion potential and sediment yield assessment models in Ozon-Dareh sub-catchment. Proceedings of the National Conference on Land Use Planning, Tehran, Iran, pp. 41-75.

Sadeghi, S. H. 2005. Semi-Detailed Technique for Soil Erosion Mapping Based on BLM and Satellite Image Applications. J. Agric. Sci. Technol. Vol. 7: 133-142.

Spalevic, V. 1999a. Application of computer-graphic methods in the studies of draining out and intensities of ground erosion in the Berane valley. Master thesis. Faculty of Agriculture of the University of Belgrade, Serbia (in Serbian). pp-131.

Spalevic, V. 2011. Impact of land use on runoff and soil erosion in Polimlje. Doctoral thesis, Faculty of Agriculture of the University of Belgrade, Serbia, p 1-260.

Spalevic, V. Curovic, M. Tanaskovic, V., Djurovic, N., Lenaerts, T. and Nyssen, J. 2015k. Application of the IntErO model for the assessment of the soil erosion intensity and runoff of the river basin Dragovo Vrelo, Montenegro (invited speaker). Balkan Agriculture Congress, 8-10 September 2014. Edirne, Turkey.

Spalevic, V., Barovic, G., Mitrovic, M., Hodzic, R., Mihajlovic, G., Frankl, A. 2015g. Assessment of sediment yield using the Erosion Potential Method (EPM) in the Karlicica Watershed of Montenegro. International Conference on Soil, Tirana, Albania; 4-7 May, 2015.

Spalevic, V., Barovic, G., Vujacic, D., Bozovic, P., Kalac, I., Nyssen, J. $2015 f$. Assessment of soil erosion in the Susica River Basin, Berane Valley, Montenegro. International Conference on Soil, Tirana, Albania; 4-7 May, 2015.

Spalevic, V., Blinkov, I., Trendafilov, A., Mukaetov, D., Djekovic, V., Djurovic, N. 2015h. Soil erosion assessment using the EPM method: A case study of the Ramcina River Basin, Montenegro. International Conference on Soil, Tirana, Albania; 4-7 May, 2015. 
Spalevic, V., Curovic, M. Tanaskovik, V., Oljaca, M., Djurovic, N. 2013b. The impact of land use on soil erosion and run-off in the Krivaja river basin in Montenegro. The First International Symposium on Agricultural Engineering, 4th - 6th October 2013, Belgrade-Zemun, Serbia, VI: 1-14.

Spalevic, V., Curovic, M., Andjelkovic, A., Djekovic, V., Ilci, S. 2014a. Calculation of soil erosion intensity in the Nedakusi Watershed of the Polimlje Region, Montenegro. International Scientific conference: Challenges in modern agricultural production, December 11, 2014, Skopje, Macedonia.

Spalevic, V., Curovic, M., Barovic, G., Florijancic, T., Boskovic, I., Kisic, I. 2015a. Assessment of Sediment Yield in the Tronosa River Basin of Montenegro. The 9th International Symposium on Plant-Soil Interactions at Low pH. October 18-23, 2015, Dubrovnik, Croatia.

Spalevic, V., Curovic, M., Barovic, G., Vujacic, D., Djurovic, N. 2015e. Soil erosion in the River Basin of Kisjele Vode, Montenegro. International conference: Land Quality and Landscape Processes, Keszthely, Hungary; 06/2015

Spalevic, V., Curovic, M., Barovic, G., Vujacic, D., Tunguz, V., Djurovic, N. 2015b. Soil erosion in the River Basin of Provala, Montenegro. Agrosym 2015, Jahorina, Bosnia and Herzegovina; 10/2015.

Spalevic, V., Curovic, M., Billi, P., Fazzini, M. Frankl, A., and Nyssen, J. 2014d. Soil erosion in the Zim Potok Watershed, Polimlje River Basin, Montenegro. The 5th International Symposium “Agrosym 2014”, Jahorina, 23-26 October 2014, Bosnia and Herzegovina, p 739-747.

Spalevic, V., Curovic, M., Povilaitis, A., Radusinovic, S. 2003a. Estimate of Maximum Outflow and Soil Erosion in the Biogradska River Basin. Monographs No1, p. 1 20. Biodiversity of the Biogradska Gora National Park; Editors: Pesic, V., Karaman, G., Spalevic, V., Jovovic, Z., Langurov, M. Department of Biology, Natural Sciences, University of Montenegro, Podogirca.

Spalevic, V., Curovic, M., Tanaskovik, V., Pivic, R., Djurovic, N. 2013e. Estimation of soil erosion intensity and runoff in the river basin of Bijeli Potok, Northeast of Montenegro. In proceeding of the 1st International Congress on Soil Science, XIII Congress of Serbian Soil Science Society "SOIL - WATER - PLANT", October, 2013. Belgrade, Serbia.

Spalevic, V., Curovic, M., Uzen, N., Simunic, I., Vukelic-Shutoska, M. 2013d. Calculation of soil erosion intensity and runoff in the river basin of Ljesnica, Northeast of Montenegro. In proceeding of the 24th International Scientific-Expert Conference on Agriculture and Food Industry, Sarajevo, Bosnia and Herzegovina.

Spalevic, V., Curovic, M., Vujacic, D., Barovic, G., Frankl, A., and Nyssen, J. $2015 i$. Assessment of soil erosion at the Brzava small watershed of Montenegro using the IntErO model. Geophysical Research Abstracts. Vol. 17, EGU2015-15007, 2015. EGU General Assembly 2015 
Spalevic, V., Djurovic, N., Mijovic, S., Vukelic-Sutoska, M., Curovic, M. 2013a. Soil Erosion Intensity and Runoff on the Djuricka River Basin (North of Montenegro). Malaysian Journal of Soil Science, Vol. 17: p.49-68.

Spalevic, V., Dlabac, A., Jovovic, Z., Rakocevic, J, Radunovic, M., Spalevic, B., Fustic, B. 1999b. The Surface and distance Measuring Program. Acta Agriculture Serbica, Vol IV, 8, p.63-71.

Spalevic, V., Dubak, D, Fustic, B, Jovovic, Z, Ristic, R. 1999c. The Estimate of the Maximum Outflow and Soil Erosion Intensity in the Kaludra River Basin. Acta Agriculture Serbica, Vol.IV, 8, p.79-89.

Spalevic, V., Frankl, A., Nyssen, J. Curovic, M. and Djurovic, N. 2015d. Calculation of soil erosion intensity in the Sutivanska Rijeka Watershed of Montenegro using the IntErO model. 2nd International Symposium for Agriculture and Food - ISAF 2015, Faculty of Agricultural Sciences and Food - Skopje, 7-9 October, 2015, Ohrid, Macedonia.

Spalevic, V., Hübl, J. Hasenauer, H. and Curovic, M. 2014c. Calculation of soil erosion intensity in the Bosnjak Watershed, Polimlje River Basin, Montenegro. The 5th International Symposium “Agrosym 2014”, Jahorina, 23-26 October 2014, Bosnia and Herzegovina, p 730-738.

Spalevic, V., Nyssen, J., Curovic, M., Lenaerts, T., Kerckhof, A., Annys, K. Van Den Branden, J., Frankl, A. 2013c. The impact of land use on soil erosion in the river basin Boljanska Rijeka in Montenegro. In proceeding of the 4th International Symposium “Agrosym 2013” (3-6 October, 2013, Jahorina, Bosnia). Key note speakers, p. 54-63.

Spalevic, V., Seker, G, Fuštić, B, Šekularac, Ristić G. 2003b. Conditions of Erosion of Soil in the Drainage Basin of the Crepulja - Lucka River: p. 287-292. International conference, "Natural and Socioeconomic effects of Erosion Control in Mountainous Regions", Banja Vrujci, Faculty of Forestry, Belgrade University, World Association of S\&W Conservation.

Spalevic, V., Tazioli, A. Djekovic, V., Andjelkovic, A., and Djurovic, N. 2014b. Assessment of soil erosion in the Lipnica Watershed, Polimlje, Montenegro. The 5th International Symposium “Agrosym 2014”, Jahorina, 23-26 October 2014, Bosnia and Herzegovina, p 723-729.

Spalevic, V., Vujacic, D., Barovic, G., Simunic, I., Moteva, M. and Tanaskovik, V. 2015c. Soil erosion evaluation in the Rastocki Potok Watershed of Montenegro using the Erosion Potential Method. 2nd International Symposium for Agriculture and Food - ISAF 2015, Faculty of Agricultural Sciences and Food - Skopje, 7-9 October, 2015, Ohrid, Macedonia.

Stoffel, M., Corona, C., Ballesteros-Cánovas, J.A., Bodoque, J.M. 2013. Dating and quantification of erosion processes based on exposed roots. Earth-Science Reviews, 123:18-34. 
Stoffel, M., Huggel, C., 2012. Effects of climate change on mass movements in mountain environments. Progress in Physical Geography 36, 421-439.

Verheijen, F.G.A., Jones, R.J.A., Rickson, R.J., Smith, C.J., 2009. Tolerable versus actual soil erosion rates in Europe. Earth-Science Reviews 94, 23-38.

Vujacic, D and Spalevic, V. 2015. Assessment of runoff and soil erosion in the Radulicka Rijeka Watershed, Polimlje, Montenegro. The 6th International Symposium Agrosym 2015, Jahorina, 15-18 October 2015, Bosnia and Herzegovina.

Yousefi, S., Kivarz, N., Ramezani, B., Rasoolzadeh, N., Naderi, N., Mirzaee, S., 2014. An Estimation of Sediment by Using Erosion Potential Method and Geographic Information Systems in Chamgardalan Watershed: A Case Study of Ilam Province, Iran. GRIB, Vol. 2 (2): XXXIV to XLI

Zia Abadi, L., Ahmadi, H., 2011. Comparison of EPM and geomorphology methods for erosion and sediment yield assessment in Kasilian Watershed, Mazandaran Province, Iran. Desert, 16: 103-109. 